\title{
Seven Cases of Anaphylaxis to Paracetamol
}

Patricia Rojas Perez-Ezquerra ${ }^{1}$, Leticia Sánchez-Morillas ${ }^{1}$

1. Department of Allergy, Hospital Central de la Cruz Roja, San José y Santa Adela, Madrid, Spain

$\square$ Corresponding author: Patricia Rojas Perez-Ezquerra, projasperezezquerra@gmail.com Disclosures can be found in Additional Information at the end of the article

\section{Abstract}

Background: Paracetamol (acetaminophen, N-acetyl-para-amino-phenol) is a well-known antipyretic and analgesic drug. Hypersensitivity reactions to paracetamol are rare. However, we report seven cases of anaphylaxis to paracetamol and a review of the literature.

Procedure: Between January 1999 and May 2012, we diagnosed seven cases of anaphylaxis to paracetamol in our Allergy Department of Hospital Central de la Cruz Roja (Madrid, Spain). During these years, we reviewed our database for all cases identified as anaphylaxis due to paracetamol. We diagnosed anaphylaxis to paracetamol in seven patients: six women (85.71\%) and one man (14.28\%). Diagnosis was based on a detailed anamnesis history, skin prick tests (SPT), intradermal tests (IDT), and oral-challenge test (OCT). We also examined whether patients tolerated aspirin in order to confirm or rule out intolerance to NSAIDs.

Results and Conclusions: We report seven cases of anaphylaxis to paracetamol. Although the results of skin testing were inconclusive, the reactions to paracetamol in our patients seem to be due to an immunological mechanism-IgE mediated. As all of our patients tolerated aspirin, the reactions were not related to cyclooxygenase inhibition. Although paracetamol is usually considered a safe drug, hypersensitivity reactions are possible and should not be overlooked when performing a full allergy study.

Categories: Internal Medicine, Allergy/Immunology

Keywords: allergy, anaphylaxis, oral challenge test, paracetamol, skin tests

\section{Introduction}

Paracetamol (acetaminophen, N-acetyl-para-amino-phenol) is a well-known antipyretic and analgesic drug. However, hypersensitivity reactions to paracetamol are rare [1-13] (Figure 1).

Received 02/19/2013 Review began 02/19/2013 Published 02/26/2013

\section{(C) Copyright 2013}

Rojas Perez-Ezquerra et al. This is an open access article distributed under the terms of the Creative Commons Attribution License CCBY 3.0., which permits unrestricted use, distribution, and reproduction in any medium, provided the original author and source are credited.

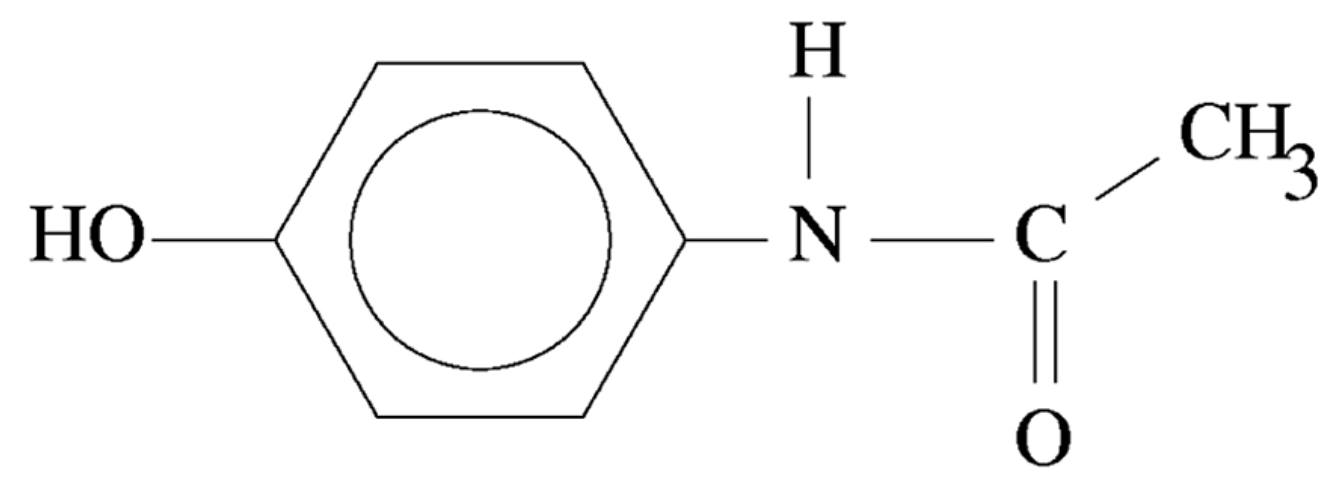

FIGURE 1: Paracetamol (acetaminophen, $\mathrm{N}$-acetyl-para-amino- 
The reactions reported usually involve intolerance to non-steroidal anti-inflammatory drugs (NSAIDs) or even dose-dependent cross-intolerance to other NSAIDs. Paracetamol minimally inhibits cyclooxygenase--it is usually considered safe for NSAID-sensitive patients, and fewer than $5 \%$ of aspirin-sensitive patients react to paracetamol in provocation tests [14-16].

Although potentially IgE-mediated allergy to paracetamol has been reported [1-10], diagnosis is based on non-standardized in vivo and in vitro tests with unknown sensitivity and specificity, and in most cases, can only be confirmed using a single-blind oral challenge test (OCT) entails risks for patients.

We present our unit data from patients diagnosed with anaphylaxis due to paracetamol during 1999-2012 and an updated review of the literature.

\section{Case Presentation}

\section{Methods}

Between January 1999 and May 2012, we diagnosed seven cases of anaphylaxis to paracetamol in our Allergy Department of Hospital Central de la Cruz Roja (Madrid, Spain). This hospital receives an average of 50,000 external patients per year. We reviewed in our database all cases identified as anaphylaxis due to paracetamol during these years.

Six cases were women (85.71\%) and one was a man (14.28\%); mean age: 36.14 years (range, 2157 years). Two patients (42.85\%) were atopic, and only one patient (14.28\%) had a family history of atopy. Diagnosis was based on a detailed anamnesis history that included symptoms highly suggestive of hypersensitivity to paracetamol. Skin prick tests (SPT), intradermal tests (IDT) and OCT were performed, if necessary. We also examined whether patients tolerated aspirin in order to confirm or exclude intolerance to NSAIDs.

We carried out SPT (10 mg/ml in saline solution) and IDT (1 and $10 \mathrm{mg} / \mathrm{ml})$ with paracetamol (Actavis Group, Zug, Switzerland). We also tested 10 control subjects (five atopic and five non-atopic). SPT and IDT were performed in two patients (28.57\%), according to the recommendations of the European Academy of Allergy and Clinical Immunology (EAACI) [1720].

After obtaining the patient's informed consent, we performed an OCT according to the protocol of the EAACI [20] in only one case that the reaction was not clear enough. In the remaining six patients, we did not perform OCT because of a history of life-threatening reaction. Oral challenges were performed with paracetamol (250, 500, and $1300 \mathrm{mg}$; doses increased at onehour intervals). All the patients had taken $1000 \mathrm{mg}$ of oral aspirin (in order to confirm or not an intolerance to NSAIDs, according to the usual protocol of EEACI), thus confirming tolerance to aspirin.

\section{Results}

Unit data: All the skin tests were negative. The OCT was positive in our patient: 15 minutes after the first intake of $250 \mathrm{mg}$, she developed dysphonia and urticaria that disappeared with intravenous methylprednisolone $80 \mathrm{mg}$ and dexclorpheniramine intramuscular and the patient did not require adrenaline. Six patients (85.71\%) were diagnosed based on a clinical history very suggestive of hypersensitivity. There were no adverse effects noted in any patient following oral administration of aspirin. 


\section{Cureus}

Literature review: We found other paracetamol anaphylaxis reported in the literature [5-9]. Skin tests are the principal way of diagnosis for an allergic reaction Ig-E mediated, like an anaphylaxis. But in many cases, tests are ineffective (Figure 2).

Our literature review revealed different concentrations for skin testing, with variations from 1 $\mathrm{mg} / \mathrm{ml}$ to $100 \mathrm{mg} / \mathrm{ml}$. Stephenson, et al. [21] reported that skin tests were not standardized and that it is very difficult to produce positive results with low-molecular-weight drugs. Few positive skin test results have been reported: Vidal, et al. [5] described one case of anaphylaxis confirmed by OCT. Serum-specific IgE antibody to paracetamol was investigated with negative results. Galindo, et al. [6] found a positive case of IDT at a concentration of $100 \mathrm{mg} / \mathrm{ml}$ in a patient with anaphylaxis. De Paramo, et al. [7] performed SPT in four patients (not IDT) and found: positive in two cases (one anaphylaxis and one one urticaria-angioedema). The authors hypothesize that the concentrations are irritating, since the patients presented wheals or erythema. Bachmeyer, et al. [8] reports one anaphylactic shock with skin prick tests, high histamine levels negatives and an OCT positive result. Rutkowski, et al. [9] described two cases positive in SPT and one in IDT.

Some authors [22-24] suggest that although skin tests provide evidence of sensitization to a specific drug, they must always be interpreted within the appropriate clinical context and not used to screen for drug allergy.

\begin{tabular}{|c|c|c|c|c|}
\hline Author & Clinic History & Skin Tests & IgE Levels & OCT \\
\hline 1.-Vidal (1997) & 1 anaphylaxis & & IgE negative & \\
\hline $\begin{array}{l}\text { 2.-Galindo } \\
\text { (1998) }\end{array}$ & 1 anaphylaxis & $\begin{array}{l}\text { SPT: positive in IDR } \\
(100 \mathrm{mg} / \mathrm{ml})\end{array}$ & RIA: negative & No (for ethical reasons) \\
\hline $\begin{array}{l}\text { 3.-De Paramo } \\
\text { (2000) }\end{array}$ & $\begin{array}{l}4 \text { cases: }-U-U-A E-2 \\
\text { anaphylaxis }\end{array}$ & $\begin{array}{l}\text { SPT: positive in } 2 / 4 \\
\text { cases }\end{array}$ & $\begin{array}{l}\text { RIA: positive in } 2 / 4 \\
\text { cases }\end{array}$ & Positive in 4/4 cases \\
\hline $\begin{array}{l}\text { 4.-Bachmeyer } \\
\text { (2002) }\end{array}$ & Anaphylactic shock & SPT: negatives & $\begin{array}{l}\text { High histamine } \\
\text { levels }\end{array}$ & Positive \\
\hline $\begin{array}{l}\text { 5.-Rutkowski } \\
\text { (2012) }\end{array}$ & 12 cases: 1 anaphylaxis & \multicolumn{2}{|c|}{ SPT + in 2 cases $(9.5 \%) 1$ IDT + (8\%) } & $\begin{array}{l}1 \text { case of anaphylaxis: } \\
\text { no tested }\end{array}$ \\
\hline
\end{tabular}

TABLE 1: Main authors with reported cases of anaphylaxis to paracetamol. SPT, skin prick test; IDR, intradermal tests, OCT, oral-challenge test; U, urticaria; AE, angioedema

\section{Discussion}

We report seven cases of anaphylaxis to paracetamol. Although the results of skin testing were inconclusive, the reactions to paracetamol in our patients seem to be due to an immunological mechanism IgE-mediated. As all of our patients tolerated aspirin, the reactions were not related to cyclooxygenase inhibition.

In cases of anaphylaxis, the OCT is a contraindication considering the risk involved for 
patients. This test should only be performed if there are diagnostic doubts and provided with all the guarantees of security and under specialist supervision. The number of skin tests was somewhat lower, probably because we underestimated the power of paracetamol to produce a true hypersensitivity reaction and the possibility that clinical manifestations associated with paracetamol could involve intolerance to NSAIDs. Skin tests results do not indicate clinical relevance in cases of this type and should not be performed [20]. The lack of serum specific IgE in vitro assays for routine clinical use meant that we were unable to use this approach to diagnose and identify patients with a suspected IgE-mediated reaction to paracetamol.

\section{Conclusions}

Although paracetamol is usually considered a safe drug, hypersensitivity reactions are possible and should not be overlooked when performing a full allergy study. Skin tests in case of anaphylaxis due to this drug are not very effective, and in many cases, diagnosis was realized with a suggestive clinical history or the gold standard in allergy tests, the OCT. It is noteworthy that case reports of allergy to paracetamol are rare and series shorts. Further multicenter studies with large series of patients are needed to confirm diagnosis and avoid the risks of the OCT.

\section{Additional Information Disclosures}

Human subjects: Consent was obtained by all participants in this study. Conflicts of interest: In compliance with the ICMJE uniform disclosure form, all authors declare the following: Payment/services info: All authors have declared that no financial support was received from any organization for the submitted work. Financial relationships: All authors have declared that they have no financial relationships at present or within the previous three years with any organizations that might have an interest in the submitted work. Other relationships: All authors have declared that there are no other relationships or activities that could appear to have influenced the submitted work.

\section{References}

1. Stricker BH, Meyboom RH, Lindquist M: Acute hypersensitivity reactions to paracetamol . Br Med J . 1985, 291:938-9. 10.1136/bmj.291.6500.938

2. Van Diem L, Grilliat JP: Anaphylactic shock induced by Paracetamol. Eur J Clin Pharmacol . 1990, 38:389 -390). 10.1007/BF00315581

3. Leung R, Plomley R, Czarny D: Paracetamol anaphylaxis. Clin Exp Allergy. 1992, 22:831- 833. 10.1111/j.1365-2222.1992.tb02827.x

4. Martin JA, Lazaro M, Cuevas M, Alvarez-Cuesta E: Hypersensitivity to Paracetamol. Med Clin (Barc). 1993, 100:158.

5. Vidal C, Perez-Carral C, Gonzalez-Quintela A: Paracetamol (acetaminophen) hypersensitivity. Ann Allergy Asthma Immunol. 1997, 79:320 -321.

6. Galindo PA, Borja J, Mur P, Feo F, Gómez E, García R: Anaphylaxis to paracetamol.. Allergol Immunopathol (Madr). 1998, 26:199-200.

7. De Paramo BJ, Gancedo SQ, Cuevas M, Camo IP, Martin JA, Cosmes EL: Paracetamol (acetaminophen) hypersensitivity. Ann Allergy Asthma Immunol. 2000, 85:508-511. 10.1016/S1081-1206(10)62580-X

8. Bachmeyer C, Vermeulen C, Habki R, Blay F, Leynadier F.S: Acetaminophen (paracetamol) induced anaphylactic shock. South Med J. 2002, 95:759-60.

9. Rutkowski S.M. Nasser P.W. Ewan: Paracetamol Hypersensitivity: Clinical Features, Mechanism and Role of Specific IgE. Int ArchAllergy Immunol . 2012;, 159:60-64. $10.1159 / 000335213$

10. Gómez Martínez M, Fernández de Miguel C, Domínguez Lázaro A, Laguna Martínez JJ, Orta Martiartu M, Lozano Ayllón M: Fixed exantema due to paracetamol. J Investig Allergol Clin 
Immunol. 1996 , 6:131-2.

11. Sehgal V: Paracetamol induced bilateral symmetrical multiple fixed drug eruption in a child . Pediatr Dermatol. 1999, 16:165-6.

12. Silva A, Proenca E, Carvalho C, Senra V, Rosano C: Fixed drug eruption induced by paracetamol. Pediatr Dermatol. 2001, 18:163-4. 10.1046/j.1525-1470.2001.018002163.x

13. Drummond C, Fischer G: Vulval fixed drug eruption due to paracetamol. Australas J Dermatol. 2009, 50:118-20. 10.1111/j.1440-0960.2009.00519.x

14. Farquhar H, Crane J, Mitchell EA, Eyers S, Beasley R: The acetaminophen and asthma hypothesis 10 years on: A case to answer. J Allergy Clin Immunol. 2009, 124:649-51.

15. Settipane RA, Stevenson DD: Cross sensitivity with acetaminophen in aspirin-sensitive subjects with asthma. J Allergy Clin Immunol. 1989, 84:26-33. 10.1016/0091-6749(89)901747

16. Brockow K, Romano A, Blanca M, Ring J, Pichler W, Demoly P: General considerations for skin test procedures in the diagnosis of drug hypersensitivity. Allergy . 2002, 57:45- 51.

10.1046/j.0105-4538.2001.00001.x-i8

17. Malling HJ: Methods of skin testing. Allergy. 1993, 14:48:55. 10.1111/j.13989995.1993.tb04757.x

18. Pastorello EA: Skin tests for diagnosis of IgE-mediated allergy . Allergy. 1993, 14:48:57. 10.1111/j.1398-9995.1993.tb04758.x

19. Aberer W, Bircher A, Romano A, Blanca M, Campi P, Fernandez J, Brockow K, Pichler W J: Drug provocation testing in the diagnosis of drug hypersensitivity reactions: general considerations. Allergy . 2003:, 58:854-863. 10.1034/j.1398-9995.2003.00279.x

20. Kowalski ML, Makowska JS, Blanca M, Bavbek S, Bochenek G, Bousquet J, Bousquet P, Celik G, Demoly P, Gomes ER, Niżankowska-Mogilnicka E, Romano A, Sanchez-Borges M, Sanz M, Torres MJ, De Weck A, Szczeklik A, Brockow K: Hypersensitivity to nonsteroidal antiinflammatory drugs (NSAIDs) - classification, diagnosis and management: review of the EAACI/ENDA(\#) and GA2LEN/HANNA*. Allergy . 2011, 66:818-29. 10.1111/j.13989995.2011.02557.x

21. Stephenson I, Nightingale JM: Commentary-anaphylactic reactions to paracetamol. Postgrad Med J. 2000, 76:503. 10.1136/pmj.76.898.503

22. Mirakian R, Ewan PW, Durham SR, Youlten LJF, Dugue P, Friedmann PS, et al: BSACI guidelines for the management of drug allergy. Clin Exp Allergy . 2009, 39:43-61. 10.1111/j.1365-2222.2008.03155.x

23. Lammintausta K, Kortekangas-Savolainen O: The usefulness of skin tests to prove drug hypersensitivity. Br J Dermatol. 2005, 152:968-74. 10.1111/j.1365-2133.2005.06429.x

24. Barbaud A, Reichert-Penetrat S, Trechot $P$ et al: The use of skin testing in the investigation of cutaneous adverse drug reactions. Br J Dermatol. 1998, 139:49-58. 10.1046/j.13652133.1998.02313.x 